\title{
Changes in Plasma Electrolytes AND BEHAVior OF FRESHWATER Fish, LUCIOBARBUS BOCAGEI, AS A FUNCTION OF ACUTE COPPER EXPOSURE
}

\author{
Fernandes Conceição ${ }^{1,2 *}$, Touir Ahlem ${ }^{2}$ and Teixeira Amilcar ${ }^{1,2}$
}

\author{
1 Centro de Investigação de Montanha (CIMO), Instituto Politécnico de Bragança, Campus de Santa Apolónia, $5300-253$ Bragança, Portugal. \\ 2 Escola Superior Agrária, Instituto Politécnico de Bragança, Campus de Santa Apolónia, 5300-253 Bragança, Portugal \\ *Corresponding author: conceicao.fernandes@ipb.pt
}

Recebido em 21 de junho de 2019. Aceito em 24 de julho de 2019. Publicado em 31 de julho de 2019.

\begin{abstract}
Plasma levels of $\mathrm{Na}^{+}, \mathrm{K}^{+}$and $\mathrm{Ca}^{2+}$ were evaluated in fish exposed / not exposed to sublethal concentrations of $\mathrm{Cu}$ to assess adverse effects on osmoregulation as well as their ability to reverse these levels. Acute toxicity tests were performed using barbells (Luciobarbus bocagei) under two different concentrations of $\mathrm{Cu}$. Barbells exposed to $\mathrm{Cu}$ showed ionic imbalance, respiratory difficulties, mortality and reduced value of $K$. According to the results, plasma levels of $\mathrm{K}^{+}$and $\mathrm{Ca}^{2+}$ increase, while plasma levels of $\mathrm{Na}^{+}$decrease, allowing the fish an osmotic adjustment and a reduction in susceptibility to $\mathrm{Cu}$. Under the conditions of this experiment, fish also showed the ability to reverse electrolyte levels when they are no longer exposed to $\mathrm{Cu}$; however, dependent on exposure concentration.
\end{abstract}

KeYworDs: Copper; Toxicity; Biomarkers; Plasma electrolytes; Luciobarbus bocagei

Alterações nos eletrólitos plasmáticos e comportamento de peiXes de Água doce, Luciobarbus bocagei, em FUNÇÃO DA EXPOSIÇÃO AGUDA AO COBRE

REsumo - Os níveis plasmáticos de $\mathrm{Na}^{+}, \mathrm{K}^{+}$e $\mathrm{Ca}^{2+}$ foram avaliados em peixes expostos/sem exposição a concentrações subletais de $\mathrm{Cu}$, para avaliar os efeitos adversos na osmorregulação, bem como a capacidade dos peixes de reverter esses níveis. Os testes de toxicidade aguda foram realizados utilizando barbos (Luciobarbus bocagę) sob duas concentrações distintas de Cu. Os barbos expostos ao $\mathrm{Cu}$ mostraram desequilíbrio iónico, dificuldades respiratórias e mortalidade e redução do valor de $K$. De acordo com os resultados, os níveis plasmáticos de $\mathrm{K}^{+}$e $\mathrm{Ca}^{2+}$ aumentam, enquanto os níveis de $\mathrm{Na}^{+}$diminuem, permitindo aos peixes um ajuste osmótico e uma redução na suscetibilidade ao Cu. Nas condições desta experiência, os peixes também mostraram capacidade para reverter os níveis de eletrólitos quando deixam de estar expostos ao Cu; no entanto, dependente da concentração de exposição.

Palavras-chaves: Cobre; Toxicidade; Biomarcadores; Eletrólitos Plasmáticos; Luciobarbus bocagei

\section{CAMbios EN LOS ELECTROLITOS PLASMÁticos Y EL COMPORTAMIENTO DE LOS PECES DE AGUA DULCE, LUCIOBARBUS BOCAGEI,} EN FUNCIÓN DE LA EXPOSICIÓN AGUDA AL COBRE.

Resumen: Se evaluaron los niveles plasmáticos de $\mathrm{Na}^{+}, \mathrm{K}^{+}$y $\mathrm{Ca}^{2+}$ en peces expuestos / sin exposición a concentraciones subletales de Cu para evaluar los efectos adversos en la osmorregulación, así como la capacidad de los peces para revertir estos niveles. Se llevaron a cabo las pruebas de toxicidad aguda con el barbo común (Luciobarbus bocagei) en dos concentraciones de $\mathrm{Cu}$ diferentes. Los barbos expuestos al $\mathrm{Cu}$ mostraron desequilibrio iónico, dificultades respiratorias, mortalidad y reducción del valor de $K$. Según los resultados, los niveles plasmáticos de $\mathrm{K}^{+}$y $\mathrm{Ca}^{2+}$ aumentan, mientras que los niveles de $\mathrm{Na}^{+}$disminuyen, permitiendo a los peces un ajuste osmótico y una reducción en la susceptibilidad al Cu. En las condiciones 
de este experimento, los peces también mostraron la capacidad de revertir los niveles de electrolitos cuando ya no están expuestos al $\mathrm{Cu}$; sin embargo, dependiente de la concentración de la exposición.

Palabras clave: Cobre; Toxicidad; Biomarcadores; Electrolitos plasmáticos; Luciobarbus bocagei

\section{INTRODUCTION}

Heavy metals are generally released in small amounts into the environment by nature processes, however, presently, there is a steady increase in their concentration in all habitats owing to anthropogenic action, such as mining, electroplating, paints and dye, battery making industries, among others. Some essential metals for animal life, such as copper, are continuously increasing in water which may result in toxic effects on aquatic live. Due to their persistence, susceptibility of accumulation in organisms, and the possibility of reaching toxic levels, metals are contaminants of great concern; however, the presence of a given metal in water or sediments does not involve direct toxicological risk to aquatic organisms. Therefore, biochemical responses of organisms-so-called biomarkers can be applied to measure exposure to toxic contaminants (Livingston 1993).

Fish, compared with invertebrates, are more sensitive to many toxicants and are convenient test-objects for water quality assessment and toxicological effects (Fernandes et al. 2011). Fish gill is an important organ with multiple functions, including gas exchange, ionic and osmotic regulation, acid-base regulation and excretion of nitrogenous wastes (Evans et al. 2005; Marshall and Grosell 2005; Evans and Claiborne 2009; Gilmour and Perry 2009). The gills of freshwater fish comprise over half of total body surface area and the mean blood to water diffusion distance is only a few microns (Hughes 1984). Gills are the first organs which come in contact with environmental pollutants and so they are particularly sensitive to physical and chemical changes in the aquatic environment (McDonald and Wood 1993). ATPases $\left(\mathrm{Na}^{+} / \mathrm{K}^{+}\right.$-ATPase, $\mathrm{Ca}^{2+}$-ATPase) are membrane-bound enzymes responsible for ions transport through membranes and, thus, they help in the regulation of osmotic pressure and membrane permeability (Evans 2008; Atli and Canl 2011). The key mechanism of metal toxicity has been reported to be an osmoregulatory impairment associated with ATPase inhibition in the osmoregulatory tissues, such as gill and kidney (Atli and Canli 2007; Saglam et al. 2013). Effects of metals on ionoregulatory gill functions have been well demonstrated, including regulation of plasma electrolytes (Mazon et al., 2002; Grosell et al. 2003; Cao et al. 2013). In fish, measurement of major electrolytes $\left(\mathrm{Na}^{+}, \mathrm{K}^{+}\right)$under stressful conditions can be used as sensitive biomarkers of chemical exposure and its effects on the ion regulating tissues (Fernandes et al. 2007, 2009; Suvetha et al. 2010). However, information on the fish ability to reverse these levels, when the stressor is not present, is scarce. In addition, although fish behavior can link physiological status to environmental conditions, generally it is not taken into account in acute toxicity studies.

The common barbell (Luciobarbus bocagel) is an endemic cyprinid of the Iberian Peninsula, with a very wide distribution, which occupies almost the entire watershed of Portugal (Magalhaes 1992). In Northeastern Portugal, different watercourses have been suffering from the negative impact of human activities, namely Portelo stream has been affected by collapse and continuous input of mining deposits, since 2009. Here, the effects detected included high Cu content and a substantial decrease on the ecological integrity status, namely a disappearance and/ or reduction of fish species (Teixeira et al. 2015).

Therefore, in the present study, acute toxicity tests with $\mathrm{Cu}$ sub-lethal concentrations were conducted in laboratory conditions, in an attempt to understand what may have occurred in fish populations. The common barbell, Luciobarbus bocagei, was chosen as an autochthonous fish species, and levels of plasmatic $\mathrm{Na}^{+}, \mathrm{K}^{+}$and $\mathrm{Ca}^{2+}$ were evaluated to assess their contribution to mitigate osmoregulatory adverse effects of $\mathrm{Cu}$. Also, the same electrolytes were measured after fish was moved to clean water, in attempt to assess fish ability to revert this situation. Behavioral responses and morphometric parameters of fish were also evaluated during the experiments. 


\section{Material and Methods}

Fish Sampling

Fish were sampled from River Sabor, located in Northeast of Portugal (Figure 1). Sampling was carried out in 3 different sites along the River, between December and April, by electrofishing (portable device Hans Grassl ELT, continuous current output of 300-600V), according to the sampling methodology of INAG (2008). After capturing, fish were transported alive in thermal bags with water to the laboratory.

Figure 1. Sampling area of River Sabor (showed by arrow).

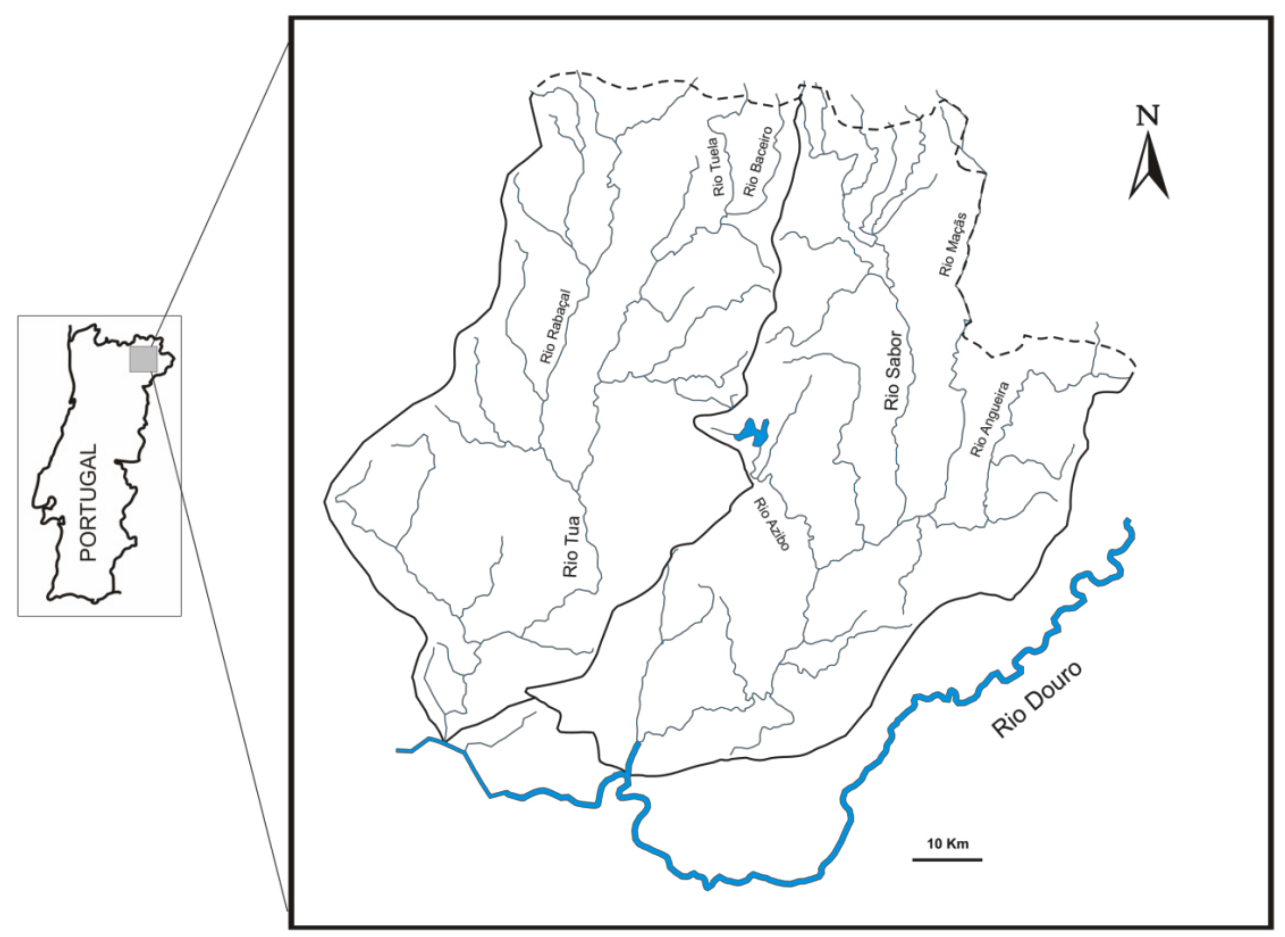

Acclimation Conditions

The toxicological tests were carried out in the Aquaculture Laboratory at Agrarian School, Bragança, Portugal. Initially, fish were acclimated for a period of 7 days in 5 tanks of $16 \mathrm{~L}$, in a closed system (Aquaneering Systems (R), with water recirculation with physical filters, activated carbon and UV, under 16h:8h photoperiod, constant temperature of $20^{\circ} \mathrm{C}$ and fed once a day, with commercial pellets, until $24 \mathrm{~h}$ before bioassays. Generally, water quality parameters during acclimation period were between desirable ranges, according to OECD (1992).

Assays of Acute Cu Exposition

Toxicological tests were carried out with Luciobarbus bocagei for 2 days in a static system, with no fish feed. Plastic tanks were filled with river water (volume of testing $70 \mathrm{~L}$ ) with aeration provided by means of pumps (aquarium pumps type) and a photoperiod of 16:8h. After the acclimatization period, fish were divided into 3 groups $(n=10$ each). One group was used as control (Control) and the other two as the exposed groups, with copper concentrations of $0.067 \pm 0.001 \mathrm{ppm}$ (Tank 1$)$ and $0.121 \pm 0.002 \mathrm{ppm}$ (Tank 2). Cu concentrations in tanks 
were obtained by dissolving certified standard solution (Merck) and measured by FAAS (Phillips PU9100X) with a calibration equation of $y=3.0193 x+0.0151 ; R^{2}=0.992 ; n=3$. The choice of $\mathrm{Cu}$ concentrations for the present toxicity tests, although lower than the ones detected during mine spill, were based on previous results with the same barbels species, which showed high fish mortality rates when higher Cu levels were applied (Monteiro 2012).

After 24h under copper exposition, five fish were removed from Tank 1 and Tank 2 for blood sampling and processing, and the remaining five fish were moved to other tanks filled with clean water, corresponding to Tank B1 and Tank B2. After 48h the remaining fish, as well as the remaining five fish from the control tank, were also taken for blood sampling and processing.

Assays were developed under two different temperatures: $19^{\circ} \mathrm{C} \pm 0.46$ and $21{ }^{\circ} \mathrm{C} \pm 0.44$. During experiments, water parameters showed a mean of all tanks for $\mathrm{pH}$ of $7.93 \pm 0.25$, for dissolved oxygen of $8.55 \pm 0.37 \mathrm{mg} / \mathrm{L}$ and for conductivity of $138 \pm 6 \mu \mathrm{S} / \mathrm{cm}$. Mean hardness value of the water has $75 \pm 5.59 \mathrm{mg} / \mathrm{L} \mathrm{CaCO}_{3}$ for the 19 ${ }^{\circ} \mathrm{C}$-assay and $54 \pm 1.71 \mathrm{mg} / \mathrm{L} \mathrm{CaCO}_{3}$ for the $21^{\circ} \mathrm{C}$-assay. Generally, water parameters during each assay of acute $\mathrm{Cu}$ exposition, considering the species wider distribution across several river basins (Alexandre et al. 2014), were within the optimum conditions for the barbels in their natural habitat. The water hardness showed a range close to the typical value of this region, with a mean value of $58.9 \mathrm{mg} / \mathrm{L} \mathrm{CaCO}_{3}$ (Brás 2013).

In all tanks, barbels were frequently observed to assess their behavior and their vital conditions. Observation of the fish was done at $0 \mathrm{~h}, 6 \mathrm{~h}, 12 \mathrm{~h}$ and after $24 \mathrm{~h}$ of $\mathrm{Cu}$ exposition, as well as during the $24 \mathrm{~h}$ under clean water.

\section{Blood Sampling and Fish Processing}

For blood sampling, barbels were anesthetized (ether ethylene glycol monophenyl, MERCK) and then blood was drawn from the caudal vessels with heparinised syringes, to eppendorf. Plasma was obtained by centrifugation (Centrifuge $5415 \mathrm{R}$ ) under cooled conditions (15 min, $10.000 \mathrm{~g}, 4^{\circ} \mathrm{C}$ ) and frozen until analysis. Plasma samples were diluted with ultra-pure water (Reverse osmose - "Water Purification System"- Series WIN Topway Global, Inc) and then total concentrations of potassium $\left(\mathrm{K}^{+}\right)$sodium $\left(\mathrm{Na}^{+}\right)$and calcium $\left(\mathrm{Ca}^{2+}\right)$ were measured by FAAS Results were expressed as $\mathrm{mM} / \mathrm{L}$.

Total body length and weight of each fish were recorded to calculate Condition Factor $(K)$, according: $K=$ body weight $(\mathrm{g}) /(\text { fish length }(\mathrm{cm}))^{3} \times 100$

All European legislation and institutional guidelines for the care and use of laboratory animals were followed and supervised by a researcher with responsibility for the functions (a), (b) and (d) stipulated by Directive 2010 / 63 / EN.

\section{DATA ANALYSIS}

Results were expressed as mean values \pm standard deviation $(\mathrm{M} \pm \mathrm{SD})$. Statistical analyses were carried out with SPSS 20.0 (SPSS Inc., Chicago, IL, USA) with a significance level of 5\%. ANOVA was applied to identify differences in mean values between $\mathrm{Cu}$ concentrations, within each set of test (weight, Condition Factor $(K), \mathrm{K}^{+}$ $\mathrm{Na}^{+}$and $\mathrm{Ca}^{2+}$ ). The Mann-Whitney test and Kolmogorov-Smirnov test were used to identify differences in mean values, within each set of test and between different tanks. 


\section{Results AND Discussion}

\section{Fish Behavior}

During acclimation period no fish mortalities were observed and behavior was considered normal. This is used as a basis for comparison to assess the health of fish during $\mathrm{Cu}$ exposition. In fact, fish behavior changes commenced to occur after $12 \mathrm{~h}$, in Tank 1 and in Tank 2, during the first assay of $\mathrm{Cu}$ exposure $\left(19^{\circ} \mathrm{C}\right)$, as in Table 1.

Table 1. Fish behavior during the first assay of $\mathrm{Cu}$ exposure $\left(19^{\circ} \mathrm{C} \pm 0.46\right)$.

\begin{tabular}{|c|c|c|c|}
\hline & $\begin{array}{c}\text { Control } \\
\mathrm{Cu}=0 \mathrm{ppm}\end{array}$ & $\begin{array}{c}\text { Tank } 1 \\
\mathrm{Cu}=0.067 \mathrm{ppm}\end{array}$ & $\begin{array}{c}\text { Tank } 2 \\
\mathrm{Cu}=0.121 \mathrm{ppm}\end{array}$ \\
\hline \multirow{4}{*}{ After $6 \mathrm{~h}$} & Normal swim & & \\
\hline & Normal equilibrium & Normal swim & Normal swim \\
\hline & Good reflex & Normal equilibrium & Normal equilibrium \\
\hline & & & Balance problems \\
\hline \multirow{6}{*}{$\begin{array}{l}\text { Between } \\
12 \mathrm{~h}-24 \mathrm{~h}\end{array}$} & & Balance problems & Swim with circular rhythm \\
\hline & Same as before & $\begin{array}{l}\text { Some fish swim in the } \\
\text { bottom and other in the } \\
\text { middle }\end{array}$ & $\begin{array}{l}\text { Every fish swim in different } \\
\text { directions }\end{array}$ \\
\hline & & & Some fish stay quite \\
\hline & & $\begin{array}{l}\text { There is some fish which } \\
\text { cannot swim easily }\end{array}$ & Some fish trying to get the surface \\
\hline & & & Some fish struggle to breath \\
\hline & $\begin{array}{c}\text { Control } \\
\mathrm{Cu}=0 \mathrm{ppm}\end{array}$ & $\begin{array}{c}\text { Tank B1 } \\
\mathrm{Cu}=0 \mathrm{ppm}\end{array}$ & $\begin{array}{c}\text { Tank B2 } \\
\mathrm{Cu}=0 \mathrm{ppm}\end{array}$ \\
\hline $\begin{array}{l}\text { Between } \\
24 h-48 h\end{array}$ & Same as before & $\begin{array}{l}\text { Same behavior as the } \\
\text { control tank }\end{array}$ & Same behavior as the control tank \\
\hline
\end{tabular}

For Tank C (without $\mathrm{Cu}$ ), fish showed a normal behavior throughout the experiment. However, in Tank 2, fish showed high stress behavior, with severe problems in balance and swim movements, including lethargic movement. On the other hand, behavior of fish in Tank 1 was less severe (Table 1), probably since fish were exposed to low Cu concentration. In this assay, no fish mortalities were observed. After the remaining fish were transferred to clean water, their behavior returned to normality, becoming similar to Tank C.

During the second assay of $\mathrm{Cu}$ exposure at $21^{\circ} \mathrm{C}$, the same behavior in Tank $\mathrm{C}$ and in Tank 1 was observed; however, all the fish in Tank 2 were dead. These fish mortality could be linked to exposition to higher $\mathrm{Cu}$ concentration associated to a higher temperature of this assay, compared to the first one, which enhanced $\mathrm{Cu}$ toxicity. Also, after the remaining fish from Tank 1 were transferred to clean water, their behavior turned again into normal condition.

Fish as a bioindicator species plays an increasingly important role in water pollution monitoring because it responds with great sensitivity to changes in aquatic environment. The effects of exposure to sub-lethal levels of pollutants can be measured in terms of several responses, including behavioral responses (Mishra and Mohanty 2008; Kumari et al. 2011). Behavior provides a unique perspective linking the physiology and ecology of an organism and its environment (Little and Brewer 2001). The results obtained here under $\mathrm{Cu}$ exposure, namely swimming 
performance and activity of fish significantly altered, are also previously observed in fish exposed to heavy metals (Little and Finger 1990; Zhou and Weis 1998; Kumari et al. 2014).

\section{Morphometric Parameters}

The assays were carried out with wild barbels randomly chosen, but as far as possible with same size class, therefore there were no differences in fish length between the two assays, nor between tanks in same assay (Table 2). For the first assay of $\mathrm{Cu}$ exposition $\left(19^{\circ} \mathrm{C}\right)$, fish length ranged between $9.80 \mathrm{~cm}$ and $12.70 \mathrm{~cm}$, whereas for the second one $\left(21^{\circ} \mathrm{C}\right)$ fish length ranged between $8.60 \mathrm{~cm}$ and $13.50 \mathrm{~cm}$. Considering the fish weight, the range for the first assay was between $6.80 \mathrm{~g}$ and $15.40 \mathrm{~g}$, and between $4.30 \mathrm{~g}$ and $15.60 \mathrm{~g}$ for the second assay. Also, there were no differences in fish weight comparing the tanks from the first assay. However, the fish weight from Tank B2 was lower than those of the other tanks (Table 2). That could have arisen from the differences between fish that were picked up between $24 \mathrm{~h}$ and $48 \mathrm{~h}$.

Table 2. Length and weight of barbels used in assays of $\mathrm{Cu}$ exposition $(\mathrm{M} \pm \mathrm{DP})$. Different letters in same row correspond to statistical differences between tanks.

\begin{tabular}{|c|c|c|c|c|}
\hline & \multicolumn{2}{|c|}{ Length $(\mathrm{cm})$} & \multicolumn{2}{|c|}{ Weight (g) } \\
\hline & $\begin{array}{c}\text { Assay } 1 \\
19^{\circ} \mathrm{C} \pm 0.46\end{array}$ & $\begin{array}{c}\text { Assay } 2 \\
21^{\circ} \mathrm{C} \pm 0.44\end{array}$ & $\begin{array}{c}\text { Assay } 1 \\
19^{\circ} \mathrm{C} \pm 0.46\end{array}$ & $\begin{array}{c}\text { Assay } 2 \\
21^{\circ} \mathrm{C} \pm 0.44\end{array}$ \\
\hline $\begin{array}{c}\text { Control } \\
\mathrm{Cu}=0 \mathrm{ppm}\end{array}$ & $11.10 \pm 0.84$ & $10.92 \pm 1.70$ & $10.42 \pm 2.66$ & $10.27 \pm 4.14^{a}$ \\
\hline $\begin{array}{c}\text { Tank } 1 \\
\mathrm{Cu}=0.067 \mathrm{ppm}\end{array}$ & $11.22 \pm 0.88$ & $10.26 \pm 0.78$ & $9.78 \pm 2.31$ & $7.28 \pm 1.04^{a}$ \\
\hline $\begin{array}{c}\text { Tank B1 } \\
\mathrm{Cu}=0 \text { ppm }\end{array}$ & $11.42 \pm 0.73$ & $9.98 \pm 0.52$ & $10.46 \pm 2.13$ & $6.90 \pm 1.16^{\mathrm{a}, \mathrm{b}}$ \\
\hline $\begin{array}{c}\text { Tank } 2 \\
\mathrm{Cu}=0.121 \mathrm{ppm}\end{array}$ & $11.18 \pm 0.85$ & $11.01 \pm 0.51$ & $10.26 \pm 2.70$ & $10.51 \pm 1.45$ \\
\hline $\begin{array}{c}\text { Tank B2 } \\
\mathrm{Cu}=0 \text { ppm }\end{array}$ & $11.62 \pm 0.50$ & $10.05 \pm 0.07$ & $10.46 \pm 1.86$ & $5.35 \pm 0.78^{b}$ \\
\hline
\end{tabular}

Standard weight in fish is the typical, or expected, weight at a given total length for a specific species of fish. As fish grow in length, they increase in weight; however the relationship between weight and length is not linear. In fact, the weight of a fish could increase more than length, or could happen that length increases more than weight, depending, among others, from feeding conditions and changes in food reserves. Therefore, relationships between weight of a fish and its length, namely the condition factor $(K)$, reflects the general condition of the fish. $K$ is a commonly measured variable that can be used as a general index of fish health (Eastwood and Couture 2002).

As Figure 2A shows, for the first assay, although fish $K$ from Tank $C$ was numerically higher than fish $K$ from Tank 1, there was no differences in fish $K$ between Tank 1 and Tank B1, nor between Tank 2 and Tank B2; i.e. all fish exposed to $\mathrm{Cu}$, and the ones removed to clean water, had the same $K$. These results suggested that $\mathrm{Cu}$ exposure, in these experimental conditions, do not affect $K$. 
Figure 2. Condition Factor (K) of barbels used in Cu exposition assays: (A) first assay; (B) second assay (different letters corresponded to significant differences).
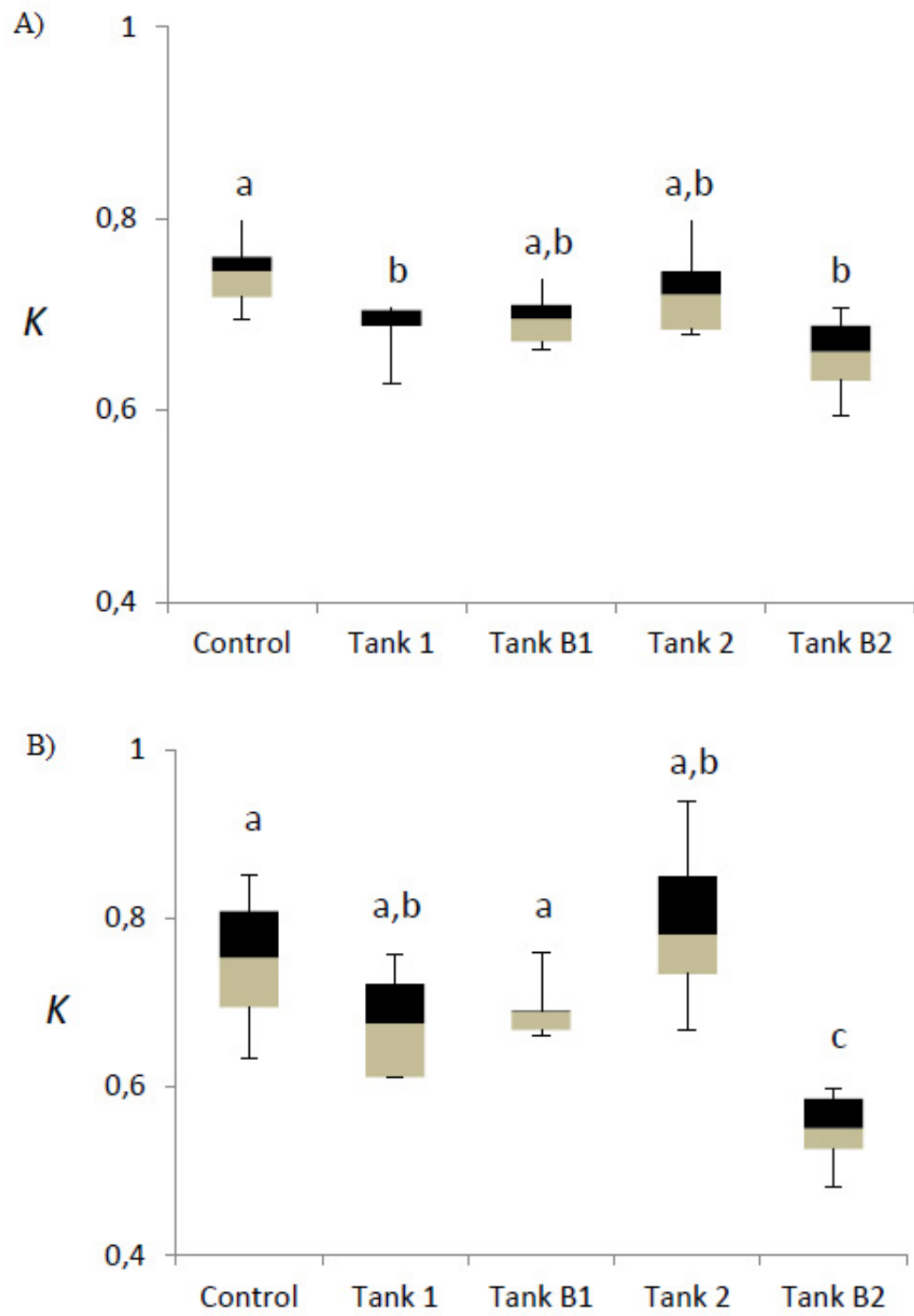

In turn, for the second assay (Figure 2B), although $K$ was similar between fish from Tank 1 and Tank B1, there was a difference in fish $K$ between Tank 2 and Tank B2. Once again, these results suggests that barbels exposed to higher $\mathrm{Cu}$ concentration in water under high temperature could be more stressed, reflecting it into a more severe behavioral response, including fish mortality, and in a lower $K$. Environmental factors affect uptake and accumulation of metals in fish, since metabolic rate is increased at high temperatures, higher uptake rates of metals may also occur. Similar effects were shown by other studies on the toxicity of $\mathrm{Cu}$ and other heavy metals, with increase of temperature (Macinnes and Calabrese 1979; Bat et al. 2000).

\section{Plasma Electrolytes}

The levels of electrolytes measured during the two assays of $\mathrm{Cu}$ acute exposition are presented in Table 3. Since there was no electrolytes differences between the two assays, comparing same type of tank, results were pooled together. 
Table 3 - Plasma levels of $\mathrm{Na}^{+}$and $\mathrm{K}^{+}(\mathrm{M} \pm \mathrm{DP})$ obtained in barbels after $24 \mathrm{~h}$ of $\mathrm{Cu}$ exposure (Tank 1 and Tank 2) and after $24 \mathrm{~h}$ in clean water (Tank B1 and Tank B2). Different letters in same column correspond to significant differences

\begin{tabular}{|c|c|c|}
\hline & Sodium $(\mathrm{mM} / \mathrm{L})$ & Potassium (mM/L) \\
\hline $\begin{array}{c}\text { Control } \\
\mathrm{Cu}=0 \mathrm{ppm}\end{array}$ & $233.422 \pm 49.706^{a}$ & $3.366 \pm 1.935^{\mathrm{a}}$ \\
\hline $\begin{array}{c}\text { Tank } 1 \\
\mathrm{Cu}=0.067 \mathrm{ppm}\end{array}$ & $166.694 \pm 45.980^{\mathrm{a}, \mathrm{b}}$ & $10.763 \pm 4.524^{b}$ \\
\hline $\begin{array}{c}\text { Tank B1 } \\
\text { Cu }=0 \text { ppm }\end{array}$ & $229.902 \pm 59.228^{a}$ & $6.107 \pm 4.811^{\mathrm{a}, \mathrm{b}}$ \\
\hline $\begin{array}{c}\text { Tank } 2 \\
\mathrm{Cu}=0.121 \mathrm{ppm}\end{array}$ & $33.239 \pm 24.554^{c}$ & $88.313 \pm 12.346^{c}$ \\
\hline $\begin{array}{c}\text { Tank B2 } \\
\mathrm{Cu}=0 \mathrm{ppm}\end{array}$ & $11.810 \pm 4.437^{c}$ & $2.922 \pm 1.444^{\mathrm{a}}$ \\
\hline
\end{tabular}

Regarding $\mathrm{K}^{+}$levels, results showed a pattern, with an increase in plasma levels of barbels exposed to $\mathrm{Cu}$, depending on $\mathrm{Cu}$ concentration, and a decrease after fish being moved to clean water, until reaching normal levels (Table 3). These results suggested that $\mathrm{K}^{+}$levels increases with $\mathrm{Cu}$ concentration, yet fish have the capacity to reverse this situation when they cease to be exposed to the toxic environment.

Instead, for $\mathrm{Na}^{+}$, it is possible to observe that barbels from Tank 1 had lower plasmatic levels compared to barbels from the control and when they were moved to clean water, they were able to increase their sodium levels (i.e., Tank B1 showed same mean values of $\mathrm{Na}^{+}$than fish from control tank). However, comparing levels from Tank 2 and Tank B2, they showed lower values of $\mathrm{Na}^{+}$than control, suggesting a stress effect due to higher $\mathrm{Cu}$ exposition (Table 3). The fish from Tank B2 after changing to clean water were not able to return to normal levels of $\mathrm{Na}^{+}$.

The $\mathrm{Ca}^{2+}$ levels were quantified during the second experiment and results showed that exposure to higher $\mathrm{Cu}$ concentration led to higher levels and, furthermore, when barbels were moved to clean water they were not able to return to $\mathrm{Ca}^{2+}$ normal levels (Figure 3).

Figure 3. Levels of calcium measured in barbels after $24 \mathrm{~h}$ of $\mathrm{Cu}$ exposure (Tank 1 and Tank 2) and after $24 \mathrm{~h}$ in clean water (Tank B1 and Tank B2).

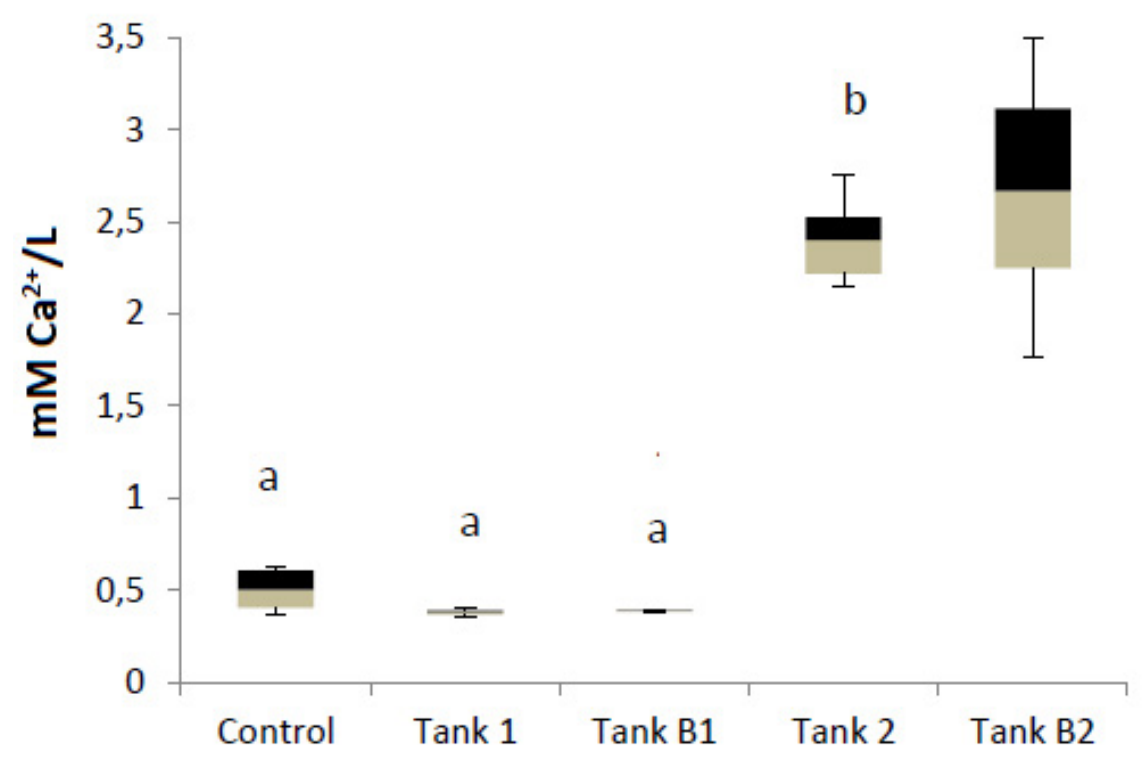


Metal ions, such as $\mathrm{Cu}^{2+}$, affect the antioxidants of fish tissues, including gills and also the active uptake of ions from water is initially impaired, leading to disturbances of ionic homeostasis (Pandey et al. 2008). The mechanisms of acute $\mathrm{Cu}$ toxicity include the osmoregulatory disturbances involving $\mathrm{Na}^{+}, \mathrm{Cl}^{-}$and $\mathrm{K}^{+}$uptake by the gill (Mazon et al. 2002; Grosell et al. 2003). Plasma $\mathrm{K}^{+}$levels may increase in fish exposed to Cu due to osmotic adjustment, when compensating for a decline of other plasma components, or resulting from disruption of $\mathrm{K}^{+}$ regulatory ability. Similar to our study, Wilson and Taylor (1993) observed a decrease in plasma $\mathrm{Na}^{+}$and an increase in plasma $\mathrm{K}^{+}$, in fresh water trout (Oncorbynchus mykiss) during the acute lethal exposure of copper. The same trend of increasing $\mathrm{K}^{+}$levels and decreasing $\mathrm{Na}^{+}$have been also observed by Monteiro (2012) and Fernandes et al. (2007, 2009), suggesting a compensatory measure to maintain ionic equilibrium. In addition, exposure of freshwater fish to $\mathrm{Cu}$ in water frequently leads to concentration-related losses of plasma ions, in particular of sodium and chloride (Li et al. 1998). The effect of copper on $\mathrm{Na}^{+}$uptake is associated with inhibition of the basolateral $\mathrm{Na}^{+} /$ $\mathrm{K}^{+}$-ATPase, leading to sodium decrease (Laurén and McDonald 1985; Mazon et al. 2002; Grosell et al. 2003; Taylor et al. 2004). Results from this study suggest that barbels under low $\mathrm{Cu}$ concentration have a decrease in enzyme activity, however, under higher $\mathrm{Cu}$ concentration, fish showed more severe injure, culminating with loss of ability to regulate $\mathrm{Na}^{+}$levels even when $\mathrm{Cu}$ is not present. Furthermore, the increasing $\mathrm{Ca}^{2+}$ observed might be related to a reduced uptake of $\mathrm{Cu}$ by gill tissue, in an attempt to minimize the toxic effects under the higher $\mathrm{Cu}$ level. In fact, $\mathrm{Cu}$ accumulation in fish gill is reduced by increasing calcium concentrations, leading to a change in susceptibility to $\mathrm{Cu}$, without altering $\mathrm{Cu}$ bioavailability (Erickson et al. 2008).

Several studies have documented different species variation in degree of tolerance to metals, for example, Salmonidae are very sensitive to contamination by metal (Pelgrom et al. 1997; Niyogi and Wood 2004), and some members of the Percidae family are known as very tolerant to metal toxicity (Niyogi and Wood 2004). However, it is important to note that most of the studies on acute toxicity tests of metals are carried out under different experimental conditions, which may explain some variation when we compare this study with others. Grosell et al. (2003) examined the effects acute exposure to different concentrations of $\mathrm{Cu}(7$ days) in two species of marine fish, Raja erinacea and Myoxocephalus octodecemspinosus and found that concentrations of serum electrolytes were not affected, in particular $\mathrm{Na}^{+}$plasma, and consequently suggested that activity of enzyme gill $\mathrm{Na}^{+} / \mathrm{K}^{+}$-ATPase was not changed. They suggested that marine fish are less $\mathrm{Cu}$ sensitive to contamination, compared to freshwater fish, since high cation concentrations in seawater can perform some protection against the toxicity of $\mathrm{Cu}$. These aspects were also mentioned by Pagenkopf (1983) and Grossel and Wood (2002), which shows that high sodium and calcium concentrations can reduce absorption and $\mathrm{Cu}$ toxicity in water salt.

During acute $\mathrm{Cu}$ exposure, barbels showed several physiological and behavioral changes, like ion imbalance, decreased aerobic scope and mortality, reduced Condition Factor $(K)$ and weight. One of the conclusions that emerge from this study is that the plasma $\mathrm{K}^{+}$and $\mathrm{Ca}^{2+}$ levels may increase and $\mathrm{Na}^{+}$levels may decrease in fish exposed to $\mathrm{Cu}$, allowing fish to an osmotic adjust and lesser susceptibility to $\mathrm{Cu}$, in an attempt to survive under a stress environment. Under the conditions of these assays, fish also showed ability to reverse the levels of electrolytes in plasma, when they cease to be exposed to $\mathrm{Cu}$; however, that is depending upon exposure concentration.

These results provided some insights into what is believed to undergo the fish populations near Portelo mines. Despite disappearance and/or reduction of fish species and degradation of habitats, it is expected that, with a gradual reduction of disturbance ecological status, a balance should be achieved.

\section{REFERENCES}

Alexandre CM, Quintella BR, Ferreira AF, Romão FA, Almeida PR (2014). Swimming performance and ecomorphology of the Iberian barbel Luciobarbus bocagei (Steindachner, 1864) on permanent and temporary rivers. Ecol Freshw Fish 23: 244-258. 
Atli G, Canli M (2007). Enzymatic responses to metal exposures in a freshwater fish Oreochromis niloticus. Comp Biochem Physiol C Toxicol Pharmacol 145: 282-287.

Atli G, Canli M (2011). Essential metal (Cu, Zn) exposures alter the activity of ATPases in gill, kidney and muscle of tilapia Oreochromis niloticus. Ecotoxicology 20: 1861-1869.

Bat L, Akbulut M, Çulha M, Gündodu A, Satilmif HH (2000). Effect of temperature on the toxicity of zinc, copper and lead to the freshwater amphipod Gammarus pulex pulex (L., 1758). Turk J Zool 24: 409-415.

Brás MSP (2013). Caracterização das Águas de Trás-os-Montes. Estudo Comparativo dos Resultados da Terra Fria e da Terra Quente. MSc, School of Agriculture, Polytechnic Institute of Bragança, Portugal.

Cao J, Chen J, Wang J, Wu X, Yu L, Xie L (2013). Tissue distributions of fluoride and its toxicity in the gills of a freshwater teleost, Cyprinus carpio. Aquat Toxicol 130-131: 68- 76.

Eastwood S, Couture P (2002). Seasonal variations in condition and liver metal concentration of yellow perch (Perca flavescens) from a metal-contaminated environment. Aquat Toxicol 58: 43-56.

Erickson RJ, Nichols JW, Cook PM, Ankley GT (2008). Bioavailability of chemical contaminants in aquatic systems. In: Di Giulio RT, Hinton DE, editors. The toxicology of fishes. CRC Press. Taylor and Francis Group, Boca Raton, pp 9-54

Evans DH (2008). Teleost fish osmoregulation: what have we learned since August Krogh Homer Smith and Ancel Keys. Am J Physiol Regul Integr Comp Physiol 295: 704-713. DOI: 10.1152/ajpregu.90337.2008

Evans DH, Claiborne JB (2009). Fish osmotic and ionic regulation. In: Evans DH, editors. Osmotic and ionic regulation: cells and animals. CRC Press. Boca Raton, pp 295-366.

Evans DH, Piermarini PM, Choe KP (2005). The multifunctional fish gill: dominant site of gas exchange, osmoregulation, acid-base regulation and excretion of nitrogenous wastes. Physiol Rev 85: 97-177.

Fernandes C, Afonso A, Salgado MA (2011). Metabolic and structural role of major fish organs as an early warning system in population assessment. In: Friedman AG, editors. Lagoons: biology, management and environmental impact. Nova Science Publishers, Inc. ISBN: 978-1-61761-738-6. pp 1-39.

Fernandes C, Fontaínhas-Fernandes A, Coimbra A, Saavedra MA, Salgado MA (2009). Biochemical blood parameters: are they effective biomarkers of chronic toxicity? In: Kungolos, Aravossis, Karagiannidis, Samaras, editors. SECOTOX Conference and the $2^{\text {nd }}$ International Conference on Environmental Management, Engineering, Planning and Economics (CEMEPE), ISBN 978-960-6865-09-1. Vol. I pp 191-196.

Fernandes C, Fontaínhas-Fernandes A, Monteiro SM, Salgado MA (2007). Changes in plasma electrolytes and gill histopathology in wild Liza saliens from the Esmoriz-Paramos coastal lagoon, Portugal. Bull Environ Contam Toxicol 79: $301-5$.

Gilmour KM, Perry SF (2009). Carbonic anhydrase and acid-base regulation in fish. J Exp Biol 212: 1647-1661.

Grosell M, Wood CM (2002). Copper uptake across rainbow trout gills: mechanisms of apical entry. J Exp Biol 205: 1179-88.

Grosell M, Wood CM, Walsh PJ (2003). Copper homeostasis and toxicity in the elasmobranch Raja erinacea and the teleost Myoxocephalus octodecemspinosus during exposure to elevated water-borne copper. Comp Biochem Physiol C 135: 179-190. 
Hughes G.M (1984). General anatomy of the gills. In: Randall DJ, editors. Fish physiology, Vol. XA, Academic Press, New York pp.1-72.

INAG (2008). Manual para a Avaliação Biológica da Qualidade da Água em Sistemas Fluviais Segundo a Directiva Quadro da Água-Protocolo de Amostragem e Análise para a Fauna Piscícola. Ministério do Ambiente, Ordenamento do Território e do Desenvolvimento Regional. Instituto da Água, I.P, Portugal.

Kumari K, Khare A, Dange S (2014). The applicability of oxidative stress biomarkers in assessing chromium induced toxicity in the fish Labeo rohita. Biomed Res Int 2014 Article ID 782493. http://dx.doi.org/10.1155/2014/782493

Kumari K, Ranjan N, Sinha RC (2011). Multiple biomarker response in the fish, Labeo robita due to hexavalent chromium. $20112^{\text {nd }}$ International Conference on Biotechnology and Food Science IPCBEE vol.7 IACSIT Press, Singapore, pp 155-158

Laurén DJ, McDonald D G (1985). Effects of copper on branchial ionoregulation in the rainbow trout, Salmo gairdneri Richardson. Modulation by water hardness and pH. J Comp Physiol B 155: 635-644.

Li J, Quabius ES, Wendelaar Bonga SE, Flik G, Lock RAC (1998). Effects of water-borne copper on branchial chloride cells and $\mathrm{Na}^{+} / \mathrm{K}^{+}$-ATPase activities in Mozambique tilapia (Oreochromis mossambicus). Aquat Toxicol 43:1-11

Little EE, Brewer S K (2001). Neurobehavioral toxicity in fish. In: Schlenk D, Benson WH, editors. Target organ toxicity in marine and fresh water teleosts. Taylor \& Francis, London, UK. pp. 140-174.

Little EE, Finger SE (1990). Swimming behavior as an indicator of sublethal toxicity in fish. Environ Toxicol Chem 9: 13-19.

Livingstone DR (1993). Biotechnology and pollution monitoring: use of molecular biomarkers in the aquatic environment. J Chem Technol Biot 57: 195-211.

Macinnes JR, Calabrese A (1979). Combined effects of salinity, temperature, and copper on embryos and early larvae of the American oyster Crassostrea virginica. Arch Environ Con Tox 8: 553-562.

Magalhaes MF (1992). Feeding ecology of the Iberian cyprinid Barbus bocagei Steindachner, 1865 in a lowland river. J Fish Biol 40: 123-133.

Marshall WS, Grosell M (2005). Ion transport, osmoregulation and acid-base balance. In: Evans and Claiborne, editors. Physiology of fishes. CRC Press, Boca Raton pp 179-214

Mazon AF, Monteiro EAS, Pinheiro GHD, Fernandes MN (2002). Hematological and physiological changes induced by short-term exposure to copper in the freshwater fish, Prochilodus scrofa. Braz J Biol 62: 621-631.

McDonald DG, Wood CM (1993). Branchial mechanisms of acclimation to metals in freshwater fish. In: Rankin JC, Jensen FB, editors. Fish ecophysiolgy. Chapman \& Hall, London, pp 297-321.

Mishra AK, Mohanty B (2008). Acute toxicity impacts of hexavalent chromium on behavior and histopathology of gill, kidney and liver of the freshwater fish, Channa punctatus (Bloch). Environ Toxicol Phar 26:136-141.

Monteiro ET (2012). Avaliação de Biomarcadores em Vertebrados Aquáticos Face à Exposição Aguda de Cobre no Meio. MSc, School of Agriculture, Polytechnic Institute of Bragança, Portugal. 
Niyogi S, Wood CM (2004). Kinetic analyses of waterborne Ca and Cd transport and their interactions in the gills of rainbow trout (Oncorbynchus mykiss) and yellow perch (Perca flavescens), two species differing greatly in acute waterborne Cd sensitivity. J Comp Physiol B 174: 243-253.

OECD (1992). Guideline for testing of chemicals - fish, acute toxicity test.

Pagenkopf RK (1983). Gill surface interaction model for trace-metal toxicity to fishes: role of complexation, $\mathrm{pH}$, and water hardness. Environ Sci Technol 17: 342- 347.

Pandey S, Parvez S, Ansari RA, Ali M, Kaur M, Hayat F, Ahmad F, Raisuddin S (2008). Effects of exposure to multiple trace metals on biochemical, histological and ultrastructural features of gills of a freshwater fish, Channa punctata Bloch. ChemBiol Interact 174: 183-192.

Pelgrom S, Lock R, Balm P, Bonga W (1997). Calcium fluxes in juvenile tilapia, Oreocbromis mossambicus, exposed to sublethal waterborne $\mathrm{Cd}, \mathrm{Cu}$ or mixtures of these metals. Environ Toxicol Chem 16: 770-774.

Saglam D, Atli G, Canli M (2013). Investigations on the osmoregulation of freshwater fish (Oreochromis niloticus) following exposures to metals $(\mathrm{Cd}, \mathrm{Cu})$ in differing hardness. Ecotox Environ Safe 92: 79-86.

Suvetha L, Ramesh M, Saravanan M (2010). Influence of cypermethrin toxicity on ionic regulation and gill $\mathrm{Na}(+) / \mathrm{K}(+)$ ATPase activity of a freshwater teleost fish Cyprinus carpio. Environ Toxicol Phar 29: 44-49.

Taylor L, Mcfarlane N WJ, Pyle GG, Couture PE, McDonald DG (2004). Use of performance indicators in evaluating chronic metal exposure in wild yellow perch (Perca flavenscens). Aquat Toxicol 67: 371-385.

Teixeira A, Fernandes C, Geraldes A, Varandas S (2015). Monitoring the impacts on the ecossystem integrity of Portelo stream (Douro basin, NE Portugal) after a large spill of mining wastes. $10^{\text {th }}$ Iberian and $7^{\text {th }}$ Iberoamerican Congress on Environmental Contamination and Toxicology, pp 314-315.

Wilson RW, Taylor EW (1993). The physiological responses of freshwater rainbow trout, Oncorbynchus mykiss, during acutely lethal copper exposure. J Comp Physiol B 163: 38-47.

Zhou T, Weis JS (1998). Swimming behavior and predator avoidance in three populations of Fundulus heteroclitus larvae after embryonic and/or larval exposure to methylmercury. Aquat Toxicol 43: 131-148. 